Fordham Law School

FLASH: The Fordham Law Archive of Scholarship and History

10-23-1984

\title{
The Office of Chief Judge of a Federal Court of Appeals
}

Wilfred Feinberg

United States Court of Appeals for the Second Circuit

Follow this and additional works at: https://ir.lawnet.fordham.edu/events_programs_sonnet_articles

Part of the Law Commons

\section{Recommended Citation}

Feinberg, Wilfred, "The Office of Chief Judge of a Federal Court of Appeals" (1984). Articles. 5.

https://ir.lawnet.fordham.edu/events_programs_sonnet_articles/5

This Book is brought to you for free and open access by the John F. Sonnett Memorial Lecture Series at FLASH: The Fordham Law Archive of Scholarship and History. It has been accepted for inclusion in Articles by an authorized administrator of FLASH: The Fordham Law Archive of Scholarship and History. For more information, please contact tmelnick@law.fordham.edu. 
ever, or if the offense indicates that the accountant exercised no care in making his judgment, the sanction could include either censure or suspension. This approach is in accord with proportionality principles established by the Supreme Court. ${ }^{112}$ The result would be a balance between the Commission's duty to protect the investing public ${ }^{113}$ and the accountant's need to make numerous decisions based on judgment. $1 / 4$

\section{CONCLUSION}

The SEC has a critical role to play in preserving honesty and integrity in the nation's financial markets. Toward this end, disciplinary rule should be employed to prevent the incompetent, dishonest or reckless accountant from practicing before the Commission. In recent years, however, the Commission has employed the "improper professional conduct" standard of its Rule 2(e) to place its own gloss on profession standards of reasonableness. As a result, the accountant does not know what behavior will constitute actionable conduct.

To limit the vagueness problems of the current improper professional conduct rule, the SEC should substitute a more specific standard. Such a standard would be provided by an approach permitting discipline of accountants who have negligently applied accounting rules but limiting the sanctions available to the Commission when the accountant has violated a rule that requires professional judgment. This standard strikes an appropriate balance between the SEC's duty to protect the investing public and the accountant's need to exercise his judgment without fear of jeopardizing his business reputation.

Michael J. Crane

112. See Solem v. Helm, 103 S. Ct. 3001, 3006-08 (1983) ("The principle that a punishment should be proportionate to the crime is deeply rooted and frequently repeated in common-law jurisprudence [and] has been recognized explicitly in this Court for almost century. "); cf., e.g., Edmund v. Forida, 458 U.S. 782, 788 (1982) (death penalty excessive for felony murder when defendant did not take life, or intend that a life be taken or that lethal force be used); Weems v. United States, 217 U.S. 349, 366-67 (1910) (sentence of years at hard labor disproportionate for crime of falsifying a public document). But Rummel v. Estelle, 44 U.S. 263, 284l.85 (1980) (1.fe inpris

felony conviction not unconstitutionally disproportionate). 195 (1976). SEC v Southwest Coal \& Energy Co., 624 F.2d 1312, 1318 (5th Cir. 1980).

114. See supra notes $16,101-06$.

\section{ARTICLES}

\section{THE OFFICE OF CHIEF JUDGE OF A FEDERAI COURT OF APPEALS}

\section{WILFRED FEINBERG*}

\section{INTRODUCTION}

THE office of chief judge of a federal court of appeals is a peculiar sort 1 of job, in many ways an invisible post on an invisible court. The Supreme Court is subject always to the glare of publicity and often so are trial judges, particularly when they preside over a notorious case. But for some reason, no one outside the legal profession seems to know very much about the courts of appeals, a state of knowledge often shared even by fellow lawyers. As I have noted elsewhere, this is both a blessing and a bane. ${ }^{1}$ The blessing is that we can go about our business, relatively undisturbed by the distractions that accompany media attention. The bane is that it is important for the body politic to understand the workings of the courts, particularly those that in the federal system operate as a court of last resort in approximately ninety-nine percent of the cases they decide, ${ }^{2}$ and are, in Judge Friendly's phrase, the "work-horses of the

- Chief Judge, United States Court of Appeals for the Second Circuit. Judge Feinberg was appointed United States circuit judge for the Second Circuit on March 7, 1966 and entered on duty March 18, 1966. He became Chief Judge on June 24, 1980. Prior to his appointment to the Second Circuit, Judge Feinberg served as a judge of the United States District Court for the Southern District of New York from October 16, 1961 to March 17, 1966. Judge Feinberg received his A.B. from Columbia College in 1940, and his LL. B. from Columbia Law School in 1946.

This Article is adapted from the Fourteenth Annual John F. Sonnett Memorial Lecture, delivered by Judge Feinberg on October 23, 1984 at the Fordham University School of Law. The text remains substantially as delivered. The assistance of H. Geoffrey Moulton, Jr., in the preparation of this Article is gratefully acknowledged.

(1983).

2. In statistical years 1981 hrough 1984, the courts of appeals decided a 00 2. 1984 Annual Report of the Director of the Administrative Office of the Uni. Courts, Courts, A-2 table B-1 hereinafter cited as 1984 Annual Reportl: AAdmin Oftce of Courts, 1983 Annual Report of the Director of the Administrative Office of the United States Courts 220 table B-1 [hereinafter cited as 1983 Annual Reportl; Admin. Office of U.S. Courts, 1982 Annual Report of the Director of the Administrative Office of the United States Courts 190, table B-1; 1981 Annual Report of the Director of the Administrative Office of the United States Courts 346, table B-1. In the same 1981-84 period, the Supreme Court decided fewer than 850 cases on certiorari from state courts and inferio federal courts. See The Supreme Court, 1983 Term, 98 Harv. L. Rev. 1, 311-12, tables II, III (1984) (194 cases decided on certiorari); The Supreme Court, 1982 Term, 97 Harv. L Rev. 1, 299-300, tables II, III (1983) (209 cases on certiorari); The Supreme Court, 1981 Term, 96 Harv. L. Rev. 1, 308-09, tables 11, II (1982) (230 cases on certiorari); The Supreme Court 1980 Term, 95 Harv. L. Rev. 1, 342-43, tables II, III (1981) (212 cases on certiorari). 
federal appellate process." 3

My focus here, however, is not on the courts of appeals, as important as they are, but on the position of chief judge of one of these courts, the lead workhorse, so to speak. That job is also an invisible one. Few fed. eral judges, let alone lawyers, can name all of the chief judges of the various federal courts of appeals. Similarly, few people are aware of what the chief judges of these courts do and of how and why they do it. Little has been written on this subject. ${ }^{4}$ This Article is designed to dispel some of that ignorance and to educate. It also offers a few modest sug. gestions for improving the chief judge's role as court administrator.

\section{HISTORY}

General MacArthur, in his famous speech to the joint houses of Congress in 1951, said "old soldiers never die; they just fade away." 5 Not long before, the reverse effect apparently occurred with the office of chief judge; it seems to have just "faded in." The position was formally created with little fanfare by the revisions of the United States Code in 1948, when the term "chief judge" in the context of a court of appeals was apparently used for the first time in a federal statute. ${ }^{6}$ The chief reviser of the Code indicated that this was a mere change in nomenclature, like the contemporaneous change in the name of the court on which a chief judge sits, from circuit court to court of appeals. ${ }^{7}$ Most of the few comentators who took note of the change thought it of no moment

3. Letter from Henry J. Friendly, Senior Circuit Judge, United States Court of Appeals for the Second Circuit, to A. Leo Levin, Executive Director, Commission on Revision of the Federal Court Appellate System (April 22, 1975), reprinted in 2 Hearings Before the Commission on Revision of the Federal Court Appellate System: Second Phase 1311, 1313 (1975)

4. The creation of the office of chief judge was attended by little comment. See sources cited infra note 8. In early 1980, the Federal Judicial Center conducted a survey of how chief judges operated and subsequently published the results. See R. Wheeler \& C. Nihan, Administering the Federal Judicial Circuits: A Survey of Chief Judges' Approaches and Procedures (Federal Judicial Center (1982)). Research has uncovered no other article-length treatment of the subject. Judge J. Edward Lumbard, a former chief judge of the Second Circuit, did discuss the job in a section of his reminiscences. See Colum. U. \& N.Y.B. Foundation, A Conversation with J. Edward Lumbard 62-79 (1980) [hereinafter cited as A Conversaton with Lumbard]. By contrast, an interesting and provocative book-length examination of the office of the Chief Justice of the United State Affairs at the Uust last year. See generally The White Burkett Miller Center of Public of chief judge of the district courts, see R. Whecler. Desk Book for Chicf Judges United States District Courts A-1 to -5 (Federal Judicial Center (1984)).

(Address to a Joint Meeting of Congress, April 19, 1951)

6. See Act of June 25, 1948, ch. 646, $\S 45$ (a), 62 Stat. 869, 871 ("The circuit judge nior in commission shall be the chief judge of the circuit."

7. Barron, The Judicial Code: 1948 Revision, 8 F.R.D. 439, 441 (1949)
At the time, the federal intermediate appellate bench was small. There pere eleven circuit courts manned by fifty-eight circuit judges. ${ }^{9}$ I use the word "manned" advisedly; there were no women at all on those courts, a word "m that happily has changed dramatically. Today, only four courts situation than be so described. ${ }^{10}$ In the text that follows, I use the masor appeals can to refer to a chief judge only for convenience, not out of culine gender the present chief judges may be so described with accuracy, that will-happily-change in the years to come.

In 1948, the largest circuit courts had an authorized complement of In 1948, the largest circuit cold the bare minimum to constiseven judgel. Only 2,758 appeals were filed in all the circuit courts in 1948:(2) 381 of those were in the Second Circuit. ${ }^{13}$ Criminal appeals na1948, tionally no right to assigned counsel in criminal appeals and no national was no right to assigned counsel in
mechanism for such appointments.

With numbers so small and with administrative matters for the court Wh a whole so few, the title of chief judge might almost have seemed out as a wh. The fundamental tenet of federal judges is that all members of a of place. The fundar In 1948, whatever privileges or precedence may have court are equal. In 1948 , whatever privileges or precedence may have custom and tradition, regardless of statute.

Much has happened in the intervening three and one-half decades. There are now 168 judges authorized for all of the thirteen courts of appeals. ${ }^{16}$ This figure represents the total of the twelve regional courtsincluding one covering the small but highly significant region of the Disincluding Columbia - and the Court of Appeals for the Federal Circuit, ${ }^{17}$ the newest circuit court. This court was born in $1982,{ }^{18}$ only a year after

tive head is needed in each circuit, and accordingly creates the office of Chief Judge of the Circuit, to be held by the Circuit Judge senior in commission.

9. There were 59 authorized court of appeals judgeships in 1948. See Act of June 25,1948 , ch. $646,844,62$ Stat. 869, 871. At the end of the year, apparently just one of these judgeships was vacant. Se.

Courts, 168 F.2d vii-xiv (1948). 10. As of December 31, 1984, the Courts

and Eighth Circuits had no female members. 11. See Act of June 25,1948 , ch. $646, \S 44,62$ Stat. 869,871 . The Eighth and Ninth Circuits each had seven authorized judgeships, while the First and the Fourth Circuits
each had three. Id.

12. Administrative Office of the United States Courts, 1948 Annual Report of the Director 118, table B-1 (1948) [hereinafter cited as 1948 Annual Report]

13. Id.

14. $I d$

15. Id

6. See 28 U.S.C.A. \$ 44(a) (West Supp. Sept. 1984)

17. See id.

18. See Federal Courts Improvements Act of 1982, Pub. L. No. 97-164, §127, 96 Stat. $25,37$.

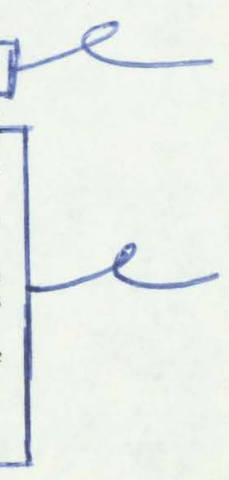


the Eleventh Circuit came into being as a spin-off from the Fifth. ${ }^{19}$ The largest court of appeals, the Ninth, has twenty-eight judges authorized. the smallest, the First, has grown from three to six. ${ }^{20}$ In the statistical year ending June 30, 1984, 31,490 appeals were filed in the circuit courts nationwide, 2,945 in the Second Circuit. ${ }^{21}$ Appeals from convictions in criminal cases comprise a significant portion of this number, ${ }^{22}$ and those who cannot afford to retain counsel have the right to have counsel appointed for them and paid by the federal government. ${ }^{23}$

The federal judicial system as a whole has become a much larger operation, of which the courts of appeals are, of course, an integral part. A sizeable infrastructure of personnel has come into being. The Administrative Office of the United States Courts was created in 1939 to assist the courts in coping with the countless problems of budget, supplies, pay scales and personnel management that are inevitably part of a system that now employs thousands of people. (24) Another institution-The Federal Judicial Center-was created in 1967 to be a research arm and to assist in the continued education of the increasing numbers of federal judges.(5) A President in a single four-year term may now appoint over 200 federal judges, as President Carter did; President Reagan appointed over 165 in his first terme 26

With this quantuum leap in scale and in scope, it was inevitable that the position of chief judge would change from its scarcely noted formal beginning in 1948. Indeed, had the job not existed, we would have had to create it. When a court goes from an authorized complement of six judges - as the Second Circuit was in $1948^{27}$ - to thirteen judges, the present number, ${ }^{28}$ plus four or five senior judges, the decisions as to who sits with whom, and when, and how the cases are distributed to these various panels become more complicated. Similarly, when a court of appeals, to help it cope with its caseload, needs to import judges who can be spared elsewhere-this is one of the little known efficiencies of the federal judicial system--someone has to decide whom to invite and for what pe riod. OO course, it is not written in granite that such decisions, and e others like them, must be made by a judicial officer, and indeed many are

19. Fifth Circuit Court of Appeals Reorganization Act of 1980, Pub. L. No. 96-452,

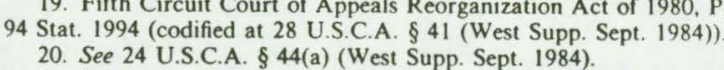

21. 1984 Annual Report, supra note 2, at A-2, table B-1.

22. See id

22. See id. 18 U.S.C. 83006 A $(1982)$

24. See Administrative Office Act of 1939, ch. 501, 53 Stat. 1223 (codified at 28 U.S.C. $\S \S 601-611(1982))$

25. See Pub. L. No. 90-219, 81 Stat. 664 (1967) (codified at 28 U.S.C. $\$ \$ 620-628$ (1982)).

26. Telephone interview with Marian Ott, Staff Assistant to the Director, AdminisIrative Office of the United States Courts (Oct. 18, 1984).

27. See Act of June 25, 1948, ch. 646, § 44(a), 62 Stat. 869, 871.

28. 28 U.S.C.A. $\$ 44($ a) (West Supp. Sept. 1984).

constitute an important new profession. ${ }^{29}$ But by common consent it appears to be accepted that some things, though administrative in nature, pears to be accepted the virtue of being should be done boured a potthere, and into thich I will describe shortly.

pourri of duties, whignificance, ConAs the position of chief judge has tantly scrutinized it and defined it gress has occasionally and almost reluctantly scrutinized it and defined it gres carefully. In 1958, aware of situations in which a chief judge had more to relinquish the post although he should have, ${ }^{30}$ Congress imrefused an age limit of seventy. ${ }^{31}$ A few years ago, there was an attempt posed an age limit of seventy. it was unsuccessful. ${ }^{2} 2$

In 1982, Congress created a further age limitation: no one over the age of sixty-four could become chief judge. ${ }^{33}$ In addition, a chief judge's term was limited to seven years. ${ }^{34}$ At the same time, Congress reaffirmed the concept that seniority determines the choice of chief judge. There the concept the with this, of course. Seniority and administrative skill do are problems with this, of cours other. My own judgment, to paraphrase not necessarily accompany each other. My own judgment, to paraphrase Winston Churchill, is that seniority is the worst way to select a chief
judge, except for all the other ways. Also, to my astonishment, it seems to work. Bb

\section{DUties}

The chief judge of a modern federal court of appeals is the head of The chief judge of a me institutions. First, he is the chicer of the what entire circuit, or do not appreciate, that the judiciary is an institution requir-

29. The office of circuit executive was created in 1971 by the Circuit Executive Act, Pub. L. No. 91-647, 84 Stat. 1907 (1971) (codified at 28 U.S.C. 8332(e), (f) (1982)). 30. See 1956 Annual Report of the Proceedings of the Judicial Conference of the United States 312 (Report of the Proceedings of a Special Session of the Judicial Conference of the United States (March 13 and 14, 1956)); S. Rep. No. 1780, 85th Cong., 2

31. Act of Aug 6, 1958, Pub. L. No.

32. See 125 Cong. Rec. 6949 (1979)

33. See 28 U.S.C. 85 (a)(1)(A) (1982). This change followed a comprehensive a commission headed by Senator Ro(he Federal Court Appellate System, man L. Hruska. See Commission on Revision of the Federal Court Appellate System, Structure and Internal Procedures: Recon

34. See 28 U.S.C. 845 (a)(3)(A) (1982). The limitation of the term to seven years does not apply to chief judges serving as such on the effective date of the act (October 1, 1982).
See Federal Cout 35. See 28 U.S.C. 845 (a) (1982)

36. It is interesting to note that while the Hruska Commission, see supra note 33, initially suggested that chief judges be selected by the Chief Justice of the United States, „e Commission on Revision of the Federal Court Appellate System, Structure and Internal Procedures: Recommendations for Change, A Preliminary Report 108-09 (1975), ultimately recommended retaining selection by seniority, see Hruska Commission Re port, supra note 33 , at 147 .

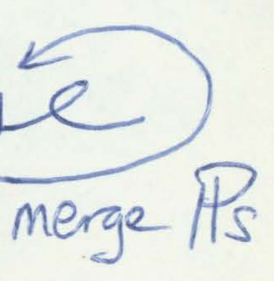

$<$ 
ing administration and that the chief judge is the chief administrator of the circuit. A number of these duties are statutory. The chief judge is also the head of the court of appeals, and many of the duties here, although not all, are governed by tradition rather than by statute.

The administrative duties of a chief judge fall into three general cate. gories: those that affect only the operation of the court of appeals itself which may be called "internal duties"; those that relate to the functioning of the federal judicial system as a whole, which may be called "systemic duties"; and those relating to the public, which may be called "external duties." Of course, these categories tend to overlap somewhat, but they are a useful basis of description.

\section{A. Internal Duties}

In the Second Circuit, it is the responsibility of the chief judge to select and organize the composition of the panels of three judges. I do that twice a year, several months in advance. This allows each of us to plan well ahead of time working schedules and other professional commitments, such as attendance at Judicial Conference committee meetings, moot courts and so on.

Such scheduling also has other less obvious but important benefits. For example, some time ago, after a decision in a highly controversial case, a lawyer for the unsuccessful appellant wrote the Clerk of the Court, sending a copy of his letter to me, questioning how it was that the case was heard by a panel that the writer obviously thought was unfriendly to his point of view. The facts were that I had designated the panel several months before without any knowledge of what cases would hear, and that much later the Clerk's office had assigned the appeal to that week and to that panel in the usual way without regard to the e composition of the panel. The Clerk's response to that effect apparently ended the matter. 37

Selecting the panels well ahead of time is not as simple as it sounds. First, we must calculate how many panels we will need to handle the probable volume. In the statistical year ended June 30, 1984, we had 51 panels. Then, we make an attempt to have each of the judges sit with as many other judges as practicable. Also, the most senior active judge presides on each panel, and in composing the panels we try to have all the judges preside a few times. Thus, the most junior active judge can and does preside, if sitting with a senior judge of the court and a visiting judge.

Presiding, like rank, has its privileges. The presiding judge assigns the opinions, if he is in the majority. But presiding also has its burdens. The presiding judge customarily prepares the bulk of the written summary orders for the week. ${ }^{38}$ The chief judge, who is by definition the most

. Last year, in addition to writsenior judge, always prished opinions, I prepared some 110 summary oring my share of published single-spaced typewritten pages ders. These are sometimes two or three single-spaced judge. I have had in length and impose a heavy burden on the presiding judge. Thave had in length an one of the newer judges tell me that they regard presiding more than did the fellow who was being ridden out of town on a rail and much as did the fellow this if it weren't for the honor of the thing!"

"wouldn't be doing the needs Moreover, schedulio res wo literally work for nothing ${ }^{39}$ and, by and desires of the senior judges, to more stress and strain than they are definition, should not be subjected to more stress and strain than they are definitirily willing to assume. They are a precious resource whose welvoluntarily wealth must be every chief judge's concern.

are and health meduling requires an estimate of how many visiting In addition, scheduling requires an estimate of heriod. The chief judge, juten with suggestions from his colleagues, decides whom to invite and often with sucessary steps; if the visitors come from outside the circuit, initiates the neces the Chief Justice of the United States must be obthe permo when the visiting judges sit it is important to obtain their pertained. Wow well or how ceptions, based on their different backgrounds, porly our court operates, as well as their suggestions for improvement. poorlly, last minute changes in the composition of a panel because of Finally, last minute chen unforeseen contingencies almost always end up recusals, illo for ind it necessary to obtain a substitute on with the chief

Another substantial portion of a chief judge's time is devoted to moniAnother substan cases through the appellate process. A court of appeal toring the flow of case in which the intake at one end is called a filing and the is like a pipeline in which the herminations, however, are outflow at the other is called a terming the expenditure of signicant judinot all of the same sort. Some require the expenditure of signifint judicial time by panels of the court. Roughly half of our appeals fall into this category. ${ }^{41}$ But the other half is disposed of in a number of ways: by settlement through our Civil Appeals Management Program (CAMP), settlement through dismissal and so on.

The pipeline in a court of appeals is quite lengthy. The median time unanimous, and each judge believes that an opinion would serve no jurisprudential purpose. See 2 d. Cir. R. $\$ 0.23$

R. 0.23 . 39. Article III judges who take senior status continue to receive their fu

Whether or not they continue to hear cases.

40. See 28 U.S.C. \$§ 291(a), 292(d) (1982). A 2 , ablc B-1 (1.224 cases decided after 41. See 1984 Annual Report, supra note 2, at A.2, abe Bin (1.224 casssion; remainder consolidated).

42. The general purpose of CAMP is to cull from the appellate docket those cases that might be settled without the further expenditure of judicial resources, and where settlement is net possible to bring more closely into focus those questions needing resolutetlement is not possible, An Apellate Procedural Reform, 74 Colum. L. Rev. 1094 (1974). 
nationally from the filing of a notice of appeal at one end of the pipeline to termination at the other is almost one year. ${ }^{43}$ In the Second Circuit, the median time is just over six months. ${ }^{44}$ But whether the time span is six months or one year or something in between, obviously someone must be watching carefully to make sure that the flow does not get unduly delayed at one point or another. $\leftarrow$

merge The responsibility for all this, in the first instance, lies with the clert and the staff in the clerk's office. But ultimately, it rests with the chief judge. If the weekly fow of cases to the panels is not even, so that some panels receive the usual twenty-four while only fifteen are ready for the next panel, the chief judge will hear about it. If the panels do not receive the briefs in sufficient time before the argument, the chief judge will hear about that, too-in no uncertain terms. In addition, the chief judge receives and studies a number of periodic reports dealing with filings, cases routed to CAMP or to our pro se clerks, cases calendared for argument, and cases argued but not yet decided sixty days after argument-all designed to minimize undue stops and starts and delays.

This system does not always run smoothly. Nothing does! Yet, by and large, because of the hard work and dedication of the judges and staff of the court, it works tolerably well. The aim is to prevent the growth of lengthy backlogs by trying to terminate in a year approximately the same number of appeals as have been filed. In the year ended June 30th, 1984, 2,945 appeals were filed and 2,952 were terminated $;^{45}$ in the year before, the figures were slightly lower but roughly in the same proportion. ${ }^{46}$

There are countless other matters affecting the internal operation of the court to which a chief judge devotes time: planning for and presiding over periodic meeting of the active judges at which all of the above matters, and others, are discussed (there are approximately five of these meetings a year); supervising the filling of the most important staff positions, such as the recent selection of our new Clerk of the Court; acting as a clearing house for the inevitable suggestions (the quaint wording still persists) for a rehearing in banc; supervising the voting - not too frequent in our circuit-when at least one judge requests a poll on an in banc hearing and-even less frequently - shepherding the in banc hearing to its conclusion when a majority of the court votes for it.

When I look at the number of in banc hearings in other circuits, realize how important a chief judge's position on their utility can be. The tradition in the Second Circuit, a tradition that goes back to Learned Hand, is that in bancs are not encouraged. My view, and that of my predecessor, Irving R. Kaufman, is that for the most part in bancs are not a good idea: They consume an enormous amount of time and often

43. Report of the Circuit Executive, United States Court of Appeals for the Second Circuit 1983, at 5, Figure 2 (1984)

44. Id.

46. 1984 Annual Report, supra note 2, at A-2, table B-1. do little to clarify the law. I firmly believe that a chief judge can play a do little to role in reducing the number of in bancs.

Finally, the chief judge acts as the ultimate chief cook and bottle Finat of other matters that may require his intervention, such washer on a host of other matters that may require his intervention as problems arinal appeals, delay by court reporters in furnishing trangents in criming a sitting by judges, and allon scripts in cases on and future, a matter exacerbated at Foley Square by chambers, present and future, a matter exacerbath the need to squeeze the judges of both the Southern District and the court of appeals into one fifty-year-old building.

Although the duties I have described up to now have grown consideraAlthough the tremendous increase in the court's filings and the not-sobly with the tremendous increase in the duties do not differ significantly tremendous increase in its judges, It is in the next two categories-sysfrom those oxternal duties-that enormous changes have occurred.

\section{B. Systemic Duties}

Each chief judge of a court of appeals is a member of the Judicial Conference of the United States ${ }^{48}$ and twice a year attends its meeting in Washington, D.C. Each meeting ordinarily lasts two days and is now usually followed on the third day by a meeting of only the chief judges. The Conference is composed of the thirteen circuit chiefs and one district The Conference is composed over by the Chief judge representative from each circuit, and is presided over by the Chief Justice. ${ }^{49}$ The Conference sets policy on a wide variety of subjects affecting the operation of the federal judiciary nationwide and its relationship with the other branches of government.

Without going into too much detail, it is almost impossible to describe We the broad range of subjects considered, most of which come in the ference by way of an extensive committee report presented in person by the Committee chairman. Let me mention just a few taken from published reports of recent proceedings. The Report of the Committee on Court Administration proposed regulations under which district courts could Aetermine whether electronic sound recordings would be a viable could determine whether electronic sound recordings would be a viable alternative to shorthand, stenotype or other methods of recording trial proceedings.(5) That committee's report also addressed, among other things, various pay and personnel practices affecting court reporters and law clerks, 31 court space requirements ${ }^{32}$ and the procedures to be followed in evaluating the need for additonal judgeships in both the district

47. Sce Kohn, Circuit Judges, Lawyers Fault Rehearings by En Banc Courts, N.Y L.J., Sept. 17, 1984, at 1, col. 1 .

48. These meetings are required by statute. See 28 U.S.C. $\$ 331$ (1982). 50. Report of the Proceedings of the Judicial Conference of the United States 47-49 (1983). 51. Id. at $49-50$.

at 54.55 .

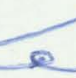



ported on the almost 1,900 financial disclosure reports filed by some 950 "judicial officers" and some 900 "judicial employees." 64 The Advisory Committee on Codes of Conduct reported on various inquiries and re sponses 25 . There were also reports from the Committees on the Admin istration of the Bankruptcy System and the Federal Magistrate

Systeme6 At the meeting I attended in September 1984, there were twenty-eight agenda items and reports. One of these was a report, which 2 received attention in the press, concerning the televising of federal court proceedings 37

Before the Conference, each member receives extensive, bulky commit tee reports and other material that will be considered at the meeting. usually takes me a couple of days simply to read this stack of documents. Until I became wiser, it took me even longer to recover from carrying it all with me to Washington, D.C. After my second meeting, it dawned on me that duplicates of all the materials were always placed at my desig nated spot at the Conference table, and I learned to read it all before went to the airport.

The meeting of chief judges after the Judicial Conference is devoted to

t. drafted and are now in effect. ${ }^{62}$ The Council's agenda, except for consideration of judicial misconduct complaints, ${ }^{63}$ is a microcosm of the Judicial Conference of the United States. The Council considers such matters as the needs of the various districts in the circuit for new district judges, bankruptcy judges and distrates, certifying of support staff for senior judges, and approval of district court plans and procedures in compliance with various statutes, such as the Criminal Justice Act, ${ }^{64}$ the Speedy Trial Act, ${ }^{65}$ and the Jury such as the Criminal Justice Act, ${ }^{64}$ the Speedy Trial Act, ${ }^{63}$ and the Jury
selection and Service Act. ${ }^{66}$ The chief judge plans for the meetings, presides at them and supervises the transaction by mail of essential business between the meetings.

Other chief judge duties involve administration of the Criminal Justice Act, an enlightened statute that transforms into reality the constitutional guarantee of the right to counsel for indigent defendants in criminal cases. ${ }^{67}$ The Act provides hourly rates of compensation to be paid by the government for court-appointed counsel in both the trial and appellate courts. ${ }^{68}$ Unfortunately, in light of inflation the rates have been much too low for several years. ${ }^{69}$ The statute also fixes maximum amounts, which may be exceeded only when the appointing judge certifies that certain statutory standards have been met and the chief judge of the circuit approves 70 Last year, over 420 vouchers were presented to me for approval; they require scrutiny and occasionally raise issues that warrant an opinion by the chief judge.

In recent years, the operation of the bankruptcy system has been a constant object of the chief judge's attention. The Bankruptcy Reform Act of 19782 designated the chief judge as the last step in a complicated process whereby bankruptcy judges were reappointed to interim terms for a period ending in 1984. 3 After a committee, composed of local representatives of a law school, a bar association and the practicing bar, had considered all objections and had nevertheless recommended reappointment, the chief judge still had to decide whether to accept the recommendation.4 The right to exercise such a veto power raised delicate and difficult issues.

Last summer chief judges all over the country were in the middle of the confusion over the status of bankruptcy judges occasioned by the de-

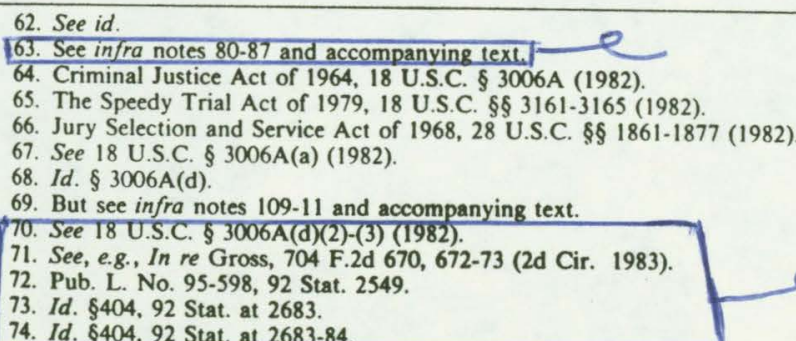
matters that concern mainly the circuit courts and is a valuable way of exchanging information and learning from each other. The chief judges also form committees to follow up on the work of the semi-annual meetings.

Closer to home, we have meetings of the Second Circuit Judicial Council, the administrative mechanism for the circuit, at least twice year. These, like the meetings of the Judicial Conference of the United States, are commanded by statute. ${ }^{58}$ Only recently, Congress passed the Judicial Councils Reform and Judicial Conduct and Disability Act of 1980 , 59 which changed the composition of the Council to require the inclusion of district as well as circuit judges $6 0 \longdiv { 5 }$

The Second Circuit Council is now composed of all the active circuit merge judges and one district judge from each of the six districts in the circuit. ${ }^{61}$ Ps

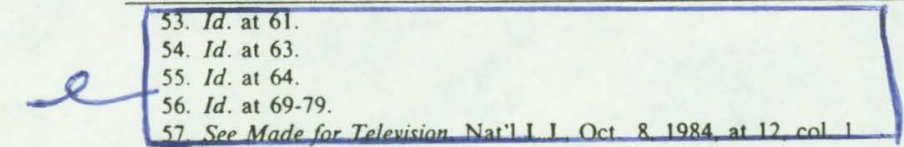

56. Id. at $69-79$ (1982)

C.). In re Restructuring the Judicial Council of the Second Circuit pursuant to the Judicial Councils Reform and Judicial Conduct and Disability Act of 1980 , Pub. L. No. 96-458, (available in files of Fordham Law Review).
7 See Made for Television Nat" I I Oct \& 1984 at 12 seat

Q U.S.C.)

61. See United States Court of Appeals and Judicial Council for the Second Circuit,

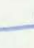

e

e
- 
lay in passing the Bankruptcy Amendments and Federal Judgeship Act, ${ }^{75}$ and had to attempt to steer an intelligent course and to answer Act, questions from judges, lo fill for new fourteen-year terms in the courts of appeals the power to 717 so that the chief judge is a the bankruptcy judgeships in the circuit, ${ }^{77}$ so that the chief judge is again in the thick of it.

Finally, with overall responsibility for operation of the circuit, the Finf judge watches the statistics of each of the district courts. When chief judge watches the stitistance, he must approve tempora district court needs additional assistance, ${ }^{78}$ as when a Southorar switching of judge-power within the circuit, ${ }^{\prime 8}$ as when a Southern District judge helps by trying cases in the District of Connecticut, or he must request the Chief Justice of the United States to approve a similar intercircuit transfer. ${ }^{79}$

\section{External Duties}

Finally, a chief judge has many responsibilities in dealing with those utside the judicial system proper but who use it or are concerned with it: the bar, the litigants, the public, the press. By far the largest time demands stem from the Judicial Councils Reform and Judicial Conduct and Disability Act of $1980,{ }^{80}$ which became effective in October 1981, and required creation and adoption of an entirely new set of local rules and required creation a complaint charg. and procedures. ing that a judicial officer "has engaged in conduct prejudicial to the tive and expeditious administration of the business of the courts, or . is unable to discharge all the duties of office by reason of mental or physical disability. "82 The Act represented a compromise, after many years of cal disability. controversy, bet ill judge and those of dealing with the occasionally senile, dish 1981 as sufficient and approwho regarded the system in effect prior to 1981 as sufficient and appro priate for the purpose ${ }^{83}$

The Act covers any complaint of misconduct against any of the some 30 judial officers anywhere in the circuit-magistrates, bankruptcy 130 judicial ofers judges, district judges and circuit judges. must go to the chief judge, who has limited options. First, he may dis-

75. Pub. L. No. 98-353, 98 Stat. 333 (1984).

See Wermiel \& Taylor, Makeshift U.S. Bankruptcy Court System Hobbles Alon Wispute About Law, Wall St. J., Aug. 19, 1984, at 37, col. 5; Riley, Bankruptcy Uncertainty Continues, Nat'I L.J., July 30, 1984, at 3, col.

st Supp. Sept. 1984)

78. See 28 U.S.C. \$ 292 (b) (1982)

9. See id. $\$ 292(d)$

8. Pe U.S.C.)

1. See $2 d$ Cir. R. $\S 0.24$

Cong. \& Ad News $4315-19$ th Con

Cong. \& Ad. News 4315-19, 4333-43. miss the complaint as frivolous or outside the scope of the Act or as directly related to the merits of a ruling, or mark it closed because cordirectly relion has been taken. ${ }^{85}$ Second, if he does not take this course, rective convene a statutory committee, composed of equal members of he must convene a statutory committee, ${ }^{86}$ Such a committee, if district and circuit judges, and himselr: then investigates and reports to the Circuit Council, which in turn has a variety of options under the statute, ranging from dismissal of the complaint to recommendation to the Judicial Conference of the United States plain impeachment. ${ }^{87}$

Every complaint must be treated with great seriousness. The record facts are obtained, the charge is considered with care, and, even if the complaint is dismissed, an order-actually a short opinion-is written. By June 30, 1984, almost fifty complaints had been filed in the Second Circuit since the effective date of the Act in October $1981^{88}$ Fach year Circuit since the efective date there has been an increase in the complaints filed. Because the Act is so new, each circuit is feeling its way in devising procedures. For example, when we had a complaint filed in the Second Circuit against all of the active circuit judges, including me, the question of who would handle it immediately arose. After obtaining views from a number of knowledgeable sources, I requested and obtained the designation of a chief judge from another circuit to act as chief judge of the circuit for the purpose of handling the complaint.

In a related vein, I mention only in passing the hundreds of letters I receive every year from frustrated pro se litigants, many of whom are incarcerated or are simply unhappy with the way they have been treated by the judicial system. I usually read each one quickly in order to send it to the appropriate person for investigation. Some of the more serious require careful attention. Of course, all judges get such correspondence but my experience has been that people suffer from the false impression that the chief judge has the power to correct all ills. Would that it were

Another major portion of the chief judge's time-again mandated by statute-is devoted to the convening and running of the annual Circuit Judicial Conference. ${ }^{89}$ In the Second Circuit, the Conferences were first held in desultory fashion, starting some forty-five years ago, 90 and took their present form about fifteen years later. J. Edward Lumbard, who was chief judge for almost twelve years and happily is still carrying a substantial workload, recently recalled in a volume of his reminiscences that Chief Judge Charles E. Clark was the first "to make something" of"

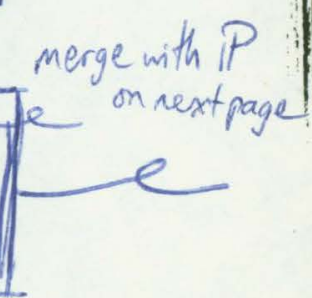

85. Id. $\$ 372(\mathrm{c})(3)$

86. Id. $\$ 372(\mathrm{c})(4)$

87. Id. $\S 372(\mathrm{c})(6)(\mathrm{B}),(\mathrm{c})(7)$

88. See 1984 Annual Report, supra note 2, at 70, table 30; 1983 Annual Report, supra note 2, at 78, table 30; 1982 Annual Report, supra note 2, at 66, table 30.

\begin{tabular}{l} 
89. See 28 U.S.C. $\$ 333$ (1982). \\
\hline 90 . See Administrative Office Act of 1939 , ch. $501, \S 306,53$ Stat. 1223, 1224 .
\end{tabular} 
inabilility to get copies of filed opinions. I refer instead to statistical reports, to speeches (such as the talk that is the basis of this Article) and to the myriad ways of letting the profession and the public know what is the myrace in the various courts in the circuit, particularly in the court taking place in the last few years, in addition to two "State of the Secof appeals. Over the Association of the Bar of the City of ond Circuit" addresses before the Associasion New York and talks at other annual bar association dinners, I have gone to meetings of local bar associations or their committees to discuss our procedures and problems, and in the case of our summary orders to exprocedures anend our practices. With regard to the latter, at times I have plain and den of lions.96-

felt like Danier of informing the public about the courts as an institution Other ways of informing the public about the courts as an institution meld in the courthouse. In all of these settings the chief judge must mainheld in the dicate balance in the judiciary's relationship with the media by tain the to meet their legitimate requests for information and to obattempting to meet their legition tain adequate publicity about the functioning of the courts while at the same time protecting confidentiality where it is essential. There are a number of other ways by which the federal courts reach out to inform and to be informed by the profession or by other courts. The state/fedan in the states involved 95 A committee on Local Rules and Internal Operin the states involved A Court of Appeals, which is mandated by statute, ${ }^{98}$ is composed of judges, lawyers and academics. The chief judge is directly involved in selecting the membership of these bodies and in following up on their recommendations.

I could go on with further illustrations of external duties, such as meeting with distinguished visitors, many from foreign countries, but I think that no more examples are needed.

\section{Ruminations and Suggestions for Change} Washington was star who had a recent stint in the executive branc thed by how much of his agency's daily agenda was set by the media in away fritol and by how different his perspective became, once he got In addition, it is essential for the public to know how the courts are operating. On a circuit-wide basis, this information is conveyed primarily by means of reports issued and speeches given by the chief judge. I do not refer here to news about a particul sponsibility of the chief judge unless a systemic problem arises, such as

1 91. A Conversation with Lumbard, supra note 4 , at 62

92. See 28 U.S.C. $\S 333$ (1982).

93. Last year was an exception: As an experiment, the conference was again held in the urban area of Hartford, Connecticut.

94. Supreme Court Workload: Hearings on H.R. 1968 Before the Subcomm. on Courts, Civil Liberties and the Administration of Justice of the House Comm. on the Judge, United Stang., Ist Sess. 150-5s (1984) (statement of Wifred Feinberg, Chief

95. See, e. S. Feinberg of Appeals for the Second Circuit).

My own ruminations about the job of chief judge are based on $m$ experience of more than four years as chief judge and, before that, some fourteen years as a circuit judge and four and one-half years as a district judge. I focus here only on the chief judge's role as an administrator and eader with regard to policies and problems that affect the court as a whole rather than on his role as a leader with regard to substantive legal whole rath

The demands of the office of chief judge are great, and quite simply cannot be appreciated until you are in it. As this Article suggests, I spend a great deal of time on what, for want of a better term, we call

96. See supra note 38 and accompanying text.

97. See Report of the Circuit Executive, Court of Appeals for the Second Circuit 1983 , at $59-60(1984)$.

98. See 28 U.S.C. $\S 2077$ (b) (1982) 
judicial administration. My rough but realistic guess is that this absorbe about fifty percent of my time. I also carry eighty percent of an active judge's usual caseload. That is, in the last few years of heavy volume, eight weeks of sitting instead of ten during the year, with approximately twenty-four appeals heard in each of those weeks. My wife has pointed

out to me with some asperity that $50 \%$ plus $80 \%$ equals $130 \%$, an obser

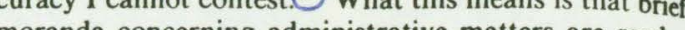
night or over the weekend and in the interstices of existence read at night or over the weekend and in the interstices of existence: on the train, in the subway, in an automobile (while someone else is driving, I hasten to add), literally, it sometimes seems during sitting weeks, in every spare moment.

The obvious question of course, is whether this load is necessary

Whether, for example) a chief judge should sit in almost as many cases as his colleagues and whether his administrative burdens can, or should, be lightened, and if so, how. The first part of this question is comparatively

e easy to answer. I put to one side the obvious For most federal judges. including this one, deciding cases is much more interesting than presiding at, or preparing for, meetings. Even after twenty-three years on the bench, despite the relentless flow of cases, many frivolous or inadequately argued, I still find it exciting to be a judge and to decide cases. Each year, there are still more appeals that sorely perplex me, and then engage me to the fullest in the attempt, never perfectly achieved, to reach the right result for the right reasons, explained clearly and concisely.

But it is for entirely different, institutional reasons that I believe that the caseload assumed by a chief judge should not be significantly lighter than that of the other active judges. As statutory responsibilities expand, chief judges will be hard-pressed to become more and more like full-time administrators. I suggest that this would be most unfortunate and that the challenge will be to prevent it from happening. If administrative duties come to consume the bulk of the chief judges' time, the courts of appeals would lose the service of their most experienced members. More importantly, the model of collegial government would tend to break down; the chief judge's problems and duties would be very different from those of his colleagues on the court, and, in time, he would cease to be perceived as one of them. He would be regarded as an admin istrator rather than as a colleague who also happens to have additional responsibilities.

The difference in perception is subtle but significant. The essence of a smoothly functioning court is collegiality. That spirit extends to every aspect of the court's operation: the number of cases it disposes of, the speed of disposition and the quality of the judicial work product. The effect of collegiality on the first two aspects is obvious. Court of appeals

99. A former clerk with a mathematical bent pointed out that if $50 \%$ of my time is spent on an $80 \%$ caseload, then in fact I spend $160 \%$ of the time I would were I not chief judge. Whatever the figure, it represents a substantial amount of time. judges work very hard-over the past several years, in the face of infudged filings, probably too hard. Last year, an active court of appeals crease in the Second Circuit sat, on the average, in 240 appeals. That judge in the judge read the briefs, heard argument except for comparatively rare submissions, and participated in the decision in 240 cases and wrote his fair share of opinions. Increased filings have also brought increase in the number of sitting weeks and in the number of cases an ineach week. No one welcomes these additional burdens, but no one is shirking the work either, and in a collegial court, each is willing to carry the load and does so.

Similarly, the Second Circuit has continued to dispose of its appeals with remarkable expedition. The median time in the Second Circuit from notice of appeal to termination has consistently been the lowest in the nation.100) Part of this stems from our practice of summary orders, which account for about sixty percent of our dispositions of cases heard or submitted.101)

Our low median time is also due to our CAMP program 102 and to our use of what we call "the 60-day list" to move opinions along. This is a list of cases undecided sixty days after argument or submission. It is examined case by case at each meeting of the court of appeals. There is no criticism of anyone on the list; almost all of us, including the chief judge, are on it from time to time. But the willingness to accept it as a useful device, like the willingness to accept the burdens of preparing detailed written orders in a short period of time, stems from a spirit of collegiality in a cooperative enterprise.

Not so obvious, perhaps, is that collegiality also improves the quality of opinions and keeps down the number of separate opinions, which often create needless confusion. When members of a panel are willing to listen to the suggestions of their colleagues regarding a proposed disposition and ultimately regarding a proposed opinion, the work product usually benefits. Three heads are almost always better than one. Do not misunderstand me; appeals court judges are usually strong-minded, independent souls. They relish criticism no more than anyone else does-perhaps less-and they are willing to accept it in a cooperative spirit only up to a point. But the location of that point is affected by the collegiality of the court. Indeed, given the Article III ${ }^{103}$ independence and the strong personalities of the judges, it is remarkable that there is so much harmony and cooperation in the Second Circuit.

I must back up a bit to clarify my thesis. I do not suggest that a chief judge alone can create such a spirit, although he could undoubtedly substantially impair it. Much more depends upon tradition, the character

101. See Report of the Circuit Executive, Court of Appeals for the Second Circuit 101. See Report of the Circuit Executive, Court of Appeals

102. See supra note 42 and accompanying text.

$e$


and personality of the judges, the indefinite chemistry when personalities meet and clash, and the panel system, which allows us to go about our business without all of us sitting with each other in each case, with the constant need to agree or disagree. But tradition may wither, and the chief judge can, by example and emphasis, help to preserve and continue valuable customs of the court, such as our voting memoranda, 104 a practice that goes back to Learned Hand and is unique, I believe, to the Second Circuit. This chief judge function is particularly important when there is a large influx of new judges to the court in a short period of time

(Moreove The chief judge can to some extent encourage collegiality in many ways through his relationships with members of the court: by building consensus, by striving to get strong-minded individuals to work together and to avoid pointless feuding, by smoothing ruffled feathers, by heading off potential crises or problems, if possible, before they arise, by emphasis on appropriate ceremonial occasions, such as inductions and memorial services in court, ${ }^{105}$ and generally by tact and concern for the welfare and feelings of his colleagues in the performance of the various duties described earlier. Obviously, this is a tall order and no chief judge can achieve it completely. But to the extent that a chief judge is able to improve collegiality at all, the perception of him primarily as colleague rather than as administrator helps.

I therefore do not find attractive the notion that a chief judge's caseload should be very much less than that of his colleagues. Where else to turn, then, to prevent the job from becoming an impossible one? An obvious answer is to lighten the administrative burdens by delegation. For example, I have in large part delegated responsibility for running the annual Second Circuit Judicial Conference 106 I do not know how many hours I spent in connection with the first such Judicial Conference for which I had ultimate responsibility, but they were many. Since then

because the governing statute allows leeway, 107 I have delegated the primary responsibilities for the program of the Conference to one of my colleagues, as Conference Chairman, and to the head of our Planning and Program Committee. This procedure has worked splendidly in the three subsequent Conferences. Although the chief judge still has much to do in connection with each Conference, his load has been reduced considerably.

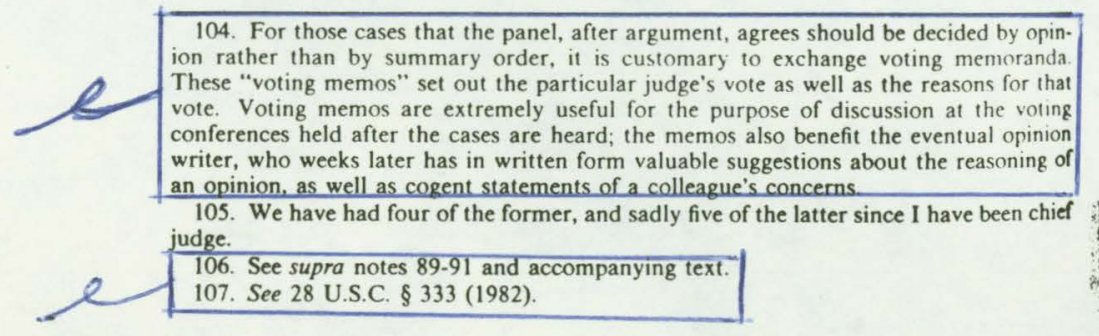

Much also be delegated to the Circuit Executive, a position created

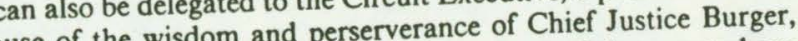
only because of the wisdom and perserverance of Chintration of the courts have whose efforts on behalf of improved administration of the courts haspensable aid been herculean. The Circuit Executive is a useful and indispensable job been heristering the circuit. Indeed, I shudder to think of what the job in admin judge would be without him. But the Circuit Executive's duties of chief judge would bircuit-wide and systemic. Even in this sphere, the are predominantly circuit-wide and systemicere chief judge has ultimate responsibility and the chief judge can perform even in addition, there are duties that only the chief judge can perform the first instance, such as atten

the first instance United States.

ference of the there are reasons for not delegating even when it is in the Frequently there are reastions ory possible. In at least one from inside the circuit or judges from judges, 108 - whether district judges from insonnel, not by a judge. I have outside the circuit-are made by staff personnel, not more effective and outside that a telephone call from the chief judge is more effective and found that a obtains a quicker respot achieved this result. I attain alputer, but in practice, we have borking closely with an experienced most the same efficient results by working as the number of staff member in meeting the various conditions, such as the nuch staf mem panels, the need to mix up the composition of panels as much as desired pane have all judges preside at least once and in fair proporpossible and to have all judges prting weeks, and so on

tions, the equitable spacing of sitting weeks, and so on. No doubt there are duties now carried out by the chief jud there are could be efficiently delegated to other members of the court, but there are limits there, as well. Not every judge is interested in taking on adminislimits there, as well trative, as distinguished from judicial, busy. But even where other judges ter at it than others, and all are quite busy. But even wibilities, Congress are willing and able to assume administrative responsibilities, Congress frequently has made delegation all but impossible. Under the Criminal Justice Act, for example, the chief judge is the only official authorized to Justice Act, for example, the che maximum amounts permitted. ${ }^{109}$ approve payments in excess of the maximu the statute should not be There is simply no persuasive reason why the member of the court seamended to allow the chief judge, or another member of the court selected by him, to perform that function. ${ }^{110}$ At the very least, the maximum amounts that trigger chief judge involvement should be raised to mum amounts that trigger chently increased them somewhat, but sufficiently."

there is no persuasive reason to confine only to Similarly, I suggest that there is no persuasive reason to con complaints of the chief judge the authority to act at the initial stage upon complaint

\section{T08 See supra note 40 and accompanying text. T 2}

109. See 18 U. S. $53006 \mathrm{~A}(\mathrm{~d})(3)(1982)$.

110. Ce Pre-trial serv110. Cf., Pretrial Services Act of

ices offer selected by pancl

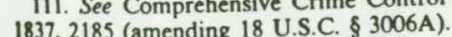


judicial misconduct. Regardless of whether experience will fortify the views of those who supported or those who opposed the statute, it may come to be perceived as an alternate appeal route for the disappointed or troubled litigant who, as I have pointed out elsewhere, ${ }^{112}$ may have grudge against the system or the world that is not amenable to any sort of legal remedy. A few months ago, I read with mounting concern a

five judges account of the hearing in open court by a statutory committee of five judges - three circuit judges, including the chief judge, and two district judges-concerning a complaint against a judge in that circuit My reaction was not based on the merits of the complaint-I have no view as to that-but on the number of judge-hours being consumed by consideration of it. In that case, a determination had already been mad that the complaint was neither frivolous, nor outside the scope of the Act, nor directly related to the merits of a ruling. I therefore do not quarrel at all with the view that the chief judge should preside over an directly participate in any further proceeding. But what about com plaints that are frivolous, or outside the scope of the Act, or directly related to the merits of a ruling, as experience has shown most so far to be? Must each of those require the personal attention of the chief judge? this initial determinate fairly and wisely this function to a colleague? I submit that it should, and that the statute should be amended to allow it. ${ }^{114}$

Similarly, as I have already noted, in 1978 Congress created an entire new set of responsibilities in connection with selection of bankruptcy judges.119) In the period from 1978 to 1984 , the chief judge alone was required by statute to decide whether to veto reappointment of incum bents (116) This was clearly not necessary. In the new Bankruptcy Act, the court of appeals has the responsibility for appointment of bankruptcy judges to new fourteen-year terms. ${ }^{118}$ Putting to one side whether this power might not better rest with the district courts, who are more knowl edgeable about the bankruptcy judges, it is still a step in the right direction. Of course, the chief judge will be intimately involved. But vesting the appointment power not in the chief judge alone, but in the court of appeals as a whole, was an improvement because it allows some room for delegation. Generally, the ability to delegate should be encouraged. It enhances the spirit of collegiality and it exposes future chief judges to the issues they will have to face. Someone remarked to me recently that 1 should be pleased because the chief judges are being given so much ad-

112 See Feinberg, Foreward to Foundation of the Fed. B. Council, The Remarkable Hands: An Affectionate Portrait vi (1983).

2. Hands: An Affectionate Portrait vi (1983).

114. See supro note 110

115. See supra notes 73-74 and accompanying text.

17. See supra note 74 and accompanying text.

118. See supra note 77 and accompanving text

inistrative power. My response is that a chief judge is getting so power'flithe soon won't have time to do anything!

\section{CONCLUSION}

the that this sketchy summary of the history of the job of chief 1 hope that the appeals and his responsibilities and some reflections of judge of a court added to an understanding of this rarely examined office. my own have added to and sort of job. The chief judge of a circuit has It is in many waysich a for enterprise in which there ultimate responsibilitecond Circuit, some 130 judicial officers and over a may be, as in the Second Circuit, some 130 judicial oficers and over a may be, employees. Yet the chief judge has little or no control over the thousand en the enterprise, the judgepower and staff available to it, the budget for the enter af space allocated to it and rates of come officer might question the wisdom-if I suppose a modern chief executive oncerition. In not the sanity - of anyone who voluntarily assumed such a position. In ddition to being a circuit-wide administrator, the chief judge is also responsible for the administration of the appellate court of which he is a sponsiber. And while serving as an administrator, he also sits as a busy member. And wet despite all of this, the job of chief appellate judge on that che responsibilities so challenging, the relationship judge is so interesting, the responsibilities so challenging, the relationship with colleagues so rewarding, and the intangible satisfaction simply of being the titular head of an historical institution so great, that the job is irresistible-at least for a while 